\title{
Menyelidiki Hubungan Guru-Siswa dan Bagaimana Korelasinya dengan Performa Menulis Siswa selama Pembelajaran Online
}

\author{
Investigating Rapport and How It Correlates with Students' Writing Performance \\ during Online Learning
}

\author{
Rahma Faridila Amaliah \& Dadang Sudana \\ Universitas Pendidikan Indonesia, Bandung, Jawa Barat, Indonesia \\ rahmaamaliah@gmail.com
}

Naskah diterima tanggal 12/03/2021, direvisi akhir tanggal 14/07/2021, disetujui tanggal 12/08/2021

\begin{abstract}
Abstrak
Penelitian ini bertujuan untuk menyelidiki strategi guru dalam membangun hubungan rapport dengan siswa dan bagaimana strategi ini berkorelasi dengan performa menulis siswa. Di dalam penelitian ini, ada dua dimensi hubungan guru-siswaketerhubungan guru dan kecemasan siswa saat berinteraksi dengan guru-maka perhitungan korelasi dilakukan secara terpisah dengan menggunakan SPSS. Metode campuran-khususnya model concurent embedded-diterapkan untuk menjawab tujuan dari penelitian ini. Hasil penelitian menunjukkan bahwa mengenali dan membantu siswa secara efektif menolong guru dalam membangun hubungan yang positif dengan siswa. Pernyataan ini kemudian didukung oleh temuan dari data kuantitatif yang menyatakan bahwa 1) terdapat korelasi positif yang signifikan antara keterhubungan guru dengan performa menulis siswa; dan 2) terdapat hubungan negatif yang signifikan antara kecemasan siswa dengan performa menulis mereka. Dari temuan yang telah diuraikan di atas, dapat disimpulkan bahwa kehadiran hubungan guru-siswa yang positif memiliki korelasi yang signifikan dengan performa menulis siswa. Hasil penelitian ini diharapkan dapat membantu guru bahasa Inggris dengan strategi yang berpotensial untuk membangun hubungan yang positif selama pembelajaran online.
\end{abstract}

Kata Kunci: Korelasi, Pembelajaran Online, Rapport, Strategi, Writing

\begin{abstract}
This study aims at investigating teacher's strategies in establishing rapport with the students and how these strategies correlate with students' writing performance. As there are two dimensions of rapport-teacher's connectedness and students' anxiety when interacting with teacher - the correlation computation is done separately by using SPSS. The mixedmethod-specifically concurrent embedded design-is then applied to answer this study's research purposes. The findings show that recognizing and supporting students effectively help the teacher to establish a positive rapport with the students. This statement is then supported by the findings from quantitative data stating that 1) there is a positive significant correlation between teacher's connectedness and students' writing performance; and 2) there is a negative significant correlation between students' anxiety and their writing performance signaling that when students' anxiety decreases, students writing performance will increase. From the findings elaborated above, it can be concluded that establishing rapport is necessary as it helps students to increase academic achievement-in this case, their writing performance. The findings of this study are then hoped to aid language teachers with potential strategies to build positive rapport during online learning.
\end{abstract}

Keywords: Correlation, Online Learning, Rapport, Strategy, Writing

How to cite (APA Style): Amaliah, R F \& Sudana, D. (2021). Menyelidiki hubungan guru-siswa dan bagaimana korelasinya dengan performa menulis siswa selama pembelajaran online. Jurnal Penelitian Pendidikan, 21 (2), 2021. 242-255. doi: https://doi.org/ 10.17509/jpp.v21i2.37412 


\section{PENDAHULUAN}

Dalam menghdapi pandemi COVID-19, pemerintah Indonesia menerapkan prinsip social distancing dan PSBB (Pembatasan Sosial Berskala Besar) di beberapa kota besar untuk menekan penyebaran virus tersebut. Kebijakan social distancing yang harus diterapkan di semua lapisan masyarakat tentunya berdampak pada semua sektor kehidupan, termasuk pendidikan. Oleh karenanya, pertemuan tatap muka di kelas tidak diperbolehkan dan pembelajaran online menjadi satu-satunya cara untuk melakukan proses belajar mengajar.

Dalam penerapan pembelajaran online, ada beberapa tantangan yang dihadapi baik oleh guru maupun siswa. Diantara tantangan yang dihadapi, beberapa penelitian (lihat Alawamleh, Al-Twait, AlSaht, 2020; Putri, Purwanto, Pramono, Asbari, Wijayanti \& Choi, 2020; Siswati, Astiena \& Savitri, 2020) menekankan bahwa interaksi dan komunikasi antara guru dan siswa menjadi salah satu aspek yang paling terpengaruh; sebagian besar siswa merasa pembelajaran online membatasi interaksi mereka dengan guru dan teman mereka yang menyebabkan mereka merasa tidak terhubung (Alawamleh et al., 2020; Putri et al., 2020) dan merasa cemas karena kurangnya hubungan emosional yang terjalin apabila dibandingkan dengan kelas tatap muka (Siswati et al., 2020). Selain itu, masalah serius lain yang muncul karena kurangnya interaksi adalah guru jarang melibatkan siswa (Fatoni, Arifiati, Nurkhayati, Nurdiawati, Fidziah, Pamungkas, Adha, Irawan, Purwanto, Julyanto \& Azizi, 2020) sehingga menyebabkan kurangnya motivasi dan keterlibatan dari sisi siswa selama kelas online (Alawamleh et al., 2020; Fatoni et al., 2020) yang pada akhirnya mempengaruhi performa akademik mereka (Lammers, Gillapsy dan Hancock, 2017). Selain berdampak pada proses pembelajaran, interaksi juga merupakan faktor penting dan paling mendasar untuk membangun dan menjalin hubungan (Harmer, 2007). Oleh karenanya, aspek lain yang mungkin terancam apabila interaksi antara guru dengan siswa tidak optimal dan tidak positif adalah tidak terjalinnya hubungan yang harmonis antara mereka. Hubungan ini dikenal juga dengan istilah rapport (hubungan guru-siswa).

Brown (2004) mendefinisikan hubungan guru-siswa sebagai hubungan yang dibangun oleh guru dengan siswanya atas dasar rasa percaya dan hormat. Berdasarkan penelitian sebelumnya, ketika seorang guru memiliki hubungan yang positif dengan siswanya, hal ini mampu membuat siswa merasa mampu, kompeten, dan kreatif (Brown, 2004); membuat siswa memperoleh prestasi yang lebih tinggi khususnya karena mereka memiliki komunikasi yang baik dengan guru mereka (Marpaung \& Cendana, 2020); menciptakan perilaku positif serta meningkatkan keterlibatan siswa selama pembelajaran (Erawati, 2016); meningkatkan motivasi siswa (Harmer, 2007); mengurangi kecemasan siswa ketika mereka perlu berinteraksi dengan guru (Creasey, Jarvis \& Knapcik, 2009; Satriani, 2020) dan mendorong siswa untuk lebih sering berinteraksi dan mengambil risiko untuk menggunakan bahasa target (Chávez, Maldonado, Zamarrón, \& Villar, 2017).

Creasey et al. (2009) mengklasifikasikan hubungan guru-siswa menjadi dua dimensi; positif dan negatif. Mereka lebih lanjut mengklaim bahwa tanda hubungan guru-siswa yang positif adalah tingginya nilai keterhubungan guru (teacher connectedness); sedangkan kecemasan siswa khususnya saat siswa berinteraksi dengan guru merupakan indikasi rapport yang negatif.

Keterhubungan guru (teacher connectedness) dikaitkan dengan seberapa dekat atau terhubung perasaan siswa terhadap guru mereka. Studi sebelumnya melaporkan bahwa siswa yang memiliki hubungan yang kuat dengan guru mereka akan mengarah pada hasil belajar yang lebih baik dan prestasi akademik yang lebih tinggi dibandingkan dengan mereka yang memiliki hubungan negatif dengan gurunya atau menganggap guru mereka tidak mendukung mereka (lihat Eccles, 2004; Pianta \& Stuhlman, 2004 sebagaimana dikutip dalam Creasey et al., 2009).

Di sisi lain, hubungan guru-siswa yang negatif dikaitkan dengan tingkat kecemasan siswa yang tinggi, terutama ketika mereka berinteraksi dengan guru mereka. Oleh karena itu, dalam penelitian ini, 
kecemasan siswa secara khusus didefinisikan sebagai perasaan cemas atau gelisah ketika siswa perlu atau harus berinteraksi dengan guru bahasa Inggris mereka selama proses menulis; misalnya menanyakan tentang tugas atau hal-hal lain yang sulit dipahami dan mereka membutuhkan bantuan guru untuk menyelesaikan masalah tersebut (Creasey et al., 2009). Selain itu, dalam penelitiannya, Creasey et al. (2009) juga menemukan bahwa siswa yang merasa tidak cemas atau takut adalah siswa yang merasa terhubung dengan guru mereka.

Adapun beberapa penelitian sebelumnya yang berhubungan dengan penelitian ini. Yang pertama adalah korelasi antara hubungan guru-siswa dan nilai akhir siswa. Sebuah penelitian yang dilakukan oleh Lammers et al. (2017) menunjukkan korelasi positif dan kuat antara hubungan guru-siswa yang positif dan nilai akhir siswa. Penelitian ini lebih lanjut menemukan bahwa siswa dengan penurunan skor hubungan guru-siswa sepanjang semester menunjukkan nilai akhir yang lebih rendah secara signifikan dibandingkan dengan mereka yang memiliki atau mempertahankan skor hubungan gurusiswa yang stabil sepanjang semester.

Yang kedua adalah hubungan antara kecemasan siswa dan performa mereka. Dalam sebuah penelitian yang dilakukan oleh Merell (2008), terungkap bahwa siswa dengan tingkat kecemasan yang tinggi tidak dapat sepenuhnya memaksimalkan kemampuannya karena kecemasan menjadi masalah yang berat bagi mereka. Untuk alasan ini, performa siswa turun secara bertahap. Di sisi lain, sebuah penelitian yang dilakukan oleh Satriani (2020) menunjukkan korelasi negatif yang signifikan antara kecemasan siswa dan performa berbicara mereka yang berarti semakin rendah skor kecemasan siswa, semakin tinggi skor performa berbicara siswa. Dengan kata lain, ini juga berarti bahwa membangun hubungan yang positif dengan siswa akan mengurangi kecemasan mereka, khususnya ketika mereka perlu berinteraksi dengan guru mereka.

Yang ketiga terkait dengan persepsi siswa terhadap strategi guru dalam membangun hubungan dengan siswanya. Para peserta dalam studi Smith dan Robertson (2020) melaporkan bahwa siswa menghargai hubungan yang mereka miliki dengan guru mereka. Para peserta (siswa) percaya bahwa dengan memiliki hubungan yang positif dengan guru mereka memainkan peran penting selama proses pembelajaran. Selanjutnya, penelitian kualitatif yang dilakukan oleh Sánchez, González dan Martínez (2013) yang berfokus pada penyelidikan persepsi siswa terkait dengan dampak hubungan guru-siswa dalam konteks EFL menemukan bahwa sikap dan kemauan siswa untuk belajar meningkat ketika guru mereka menunjukkan sikap yang positif; terutama sikap guru yang menunjukkan kepedulian, minat terhadap perkembangan siswa, dan rasa hormat.

Selain itu, sehubungan dengan pentingnya menjalin hubungan guru-siswa yang positif, Bruney (2012) sebagaimana dikutip dalam Nova (2017) menemukan bahwa proses pengajaran tidak akan efektif jika hubungan antara guru dan siswa tidak terjalin dengan baik. Hal ini sejalan dengan Kolawoleolanrewaju, Oluwakemi, dan Temidayo (2014) sebagaimana dikutip dalam Smith dan Roberson (2020) yang menemukan bahwa hubungan guru-siswa mempengaruhi keberhasilan akademik dan perkembangan emosional siswa serta membawa pengaruh positif pada proses belajar mengajar. Lebih dari itu, ketika hubungan positif berhasil dibangun, siswa tidak hanya akan memperoleh nilai akademik yang tinggi, mereka juga akan memiliki perilaku positif terhadap pembelajaran (Erawati, 2016). Selain itu, memiliki hubungan guru-siswa yang positif juga akan mempengaruhi motivasi belajar siswa. Pernyataan ini didukung oleh Sánchez et al. (2013) yang menemukan bahwa siswa di dalam studi mereka merasa lebih percaya diri, nyaman, dan termotivasi sebagai hasil dari hubungan guru-siswayang positif.

Dari penjelasan di atas, khususnya penjelasan yang diperoleh dari penelitian sebelumnya, dapat disimpulkan setidaknya ada enam aspek positif yang dapat diperoleh ketika seorang guru memiliki hubungan yang positif dengan siswanya termasuk: prestasi yang lebih tinggi, perilaku yang positif, 
keterlibatan yang lebih tinggi, motivasi yang lebih tinggi, dan kecemasan yang lebih rendah. Kemudian, melihat pentingnya kehadiran dan peranan rapport yang positif terhadap proses pembelajaran, peneliti memutuskan untuk menyelidiki rapport, khususnya di area yang masih kurang diselidiki pada penelitian-penelitian sebelumnya di negara Indonesia. Untuk lebih jelasnya, penelitian ini terfokus pada strategi yang dilakukan guru dalam membangun rapport selama pembelajaran online dengan siswanya dan korelasi antara dua dimensi rapport dengan performa menulis siswa selama pembelajaran online.

\section{METODE PENELITIAN}

Penelitian ini dilakukan dengan metodologi campuran (mixed method) mengingat proses pengumpulan dan analisis data dilakukan dengan menggunakan pendekatan kualitatif dan kuantitatif. Selanjutnya, karena ada tiga jenis metodologi campuran-konkuren, sekuensial, dan konversipenelitian ini menggunakan desain konkuren (Creswell, Plano, Gutmann, \& Hanson, 2006). Konkuren dipilih karena proses pengumpulan kedua jenis data-kualitatif dan kuantitatif-dilakukan dalam kurun waktu yang sama atau berdekatan dan juga karena penelitian ini memerlukan data kuantitatif untuk menjawab satu pertanyaan yang mana sebagian besar dari penelitian ini bersifat kualitatif. Selanjutnya, data kualitatif dikumpulkan untuk menjawab pertanyaan penelitian pertama, yakni yang berkaitan dengan strategi guru dalam membangun rapport dengan siswanya. Data ini diperoleh dari observasi kelas dan wawancara. Di sisi lain, data kuantitatif diselidiki untuk menjawab pertanyaan kedua; korelasi antara dua dimensi rapport dengan performa menulis siswa. Data ini didapatkan dari kuisioner dan tes menulis.

Sebelum melakukan penelitian, peneliti sebelumnya telah memastikan lokasi penelitian sesuai dengan tujuan penelitian ini, khususnya dengan melakukan wawancara singkat kepada beberapa siswa kelas tiga di salah satu SMA di Jawa Barat. Berdasar pada data yang diperoleh dari wawancara, ada tiga alasan utama mengapa lokasi dan responden ini dipilih, yaitu: pertama, berkaitan dengan pengalaman kerja guru; kedua, guru - melalui wawancara-dikenal memiliki hubungan yang baik dan positif dengan siswa selama pembelajaran tatap muka; dan ketiga, guru yang sama juga mengajar siswa kelas sepuluh SMA. Alasan mengapa siswa angkatan ini dipilih secara khusus adalah karena peneliti ingin memastikan bahwa tidak ada hubungan yang sebelumnya mungkin telah terjalin antara guru dan siswa yang akan dijadikan sebagai responden sebelum penelitian dilakukan.

Mengingat ukuran responden yang lebih besar akan lebih mungkin untuk menghasilkan signifikansi. Untuk alasan ini, mereka menyatakan ukuran responden minimum adalah 30 peserta. Adapun untuk penelitian ini, 70 siswa menjadi responden dan 3 guru terlibat-hanya satu guru yang menjadi responden penelitian, sedangkan dua guru lainnya hanya membantu menilai teks siswa. Hal ini sangat perlu dilakukan khususnya untuk memastikan skor nilai yang diberikan dapat dipercaya dan valid.

Sebelum penelitian dilakukan, instrumen penelitian diujicobakan melalui tes uji coba (pilot test) untuk mengidentifikasi pernyataan pada kuisioner yang mungkin kurang dipahami oleh peserta; mengukur validitas dan reliabilitas kuisioner, penilaian guru terhadap teks siswa, dan rubrik penilaian performa menulis siswa; dan untuk memastikan tidak ada perbedaan pendapat di antara penilai (scorer) selama proses penilaian. Kemudian, berdasarkan hasil dari tes uji coba, semua instrumen-kuisioner, penilaian guru terhadap teks siswa, dan rubrik penilaian performa menulis siswa-dinyatakan valid dan dapat dipercaya.

Teknik pengumpulan data dalam penelitian ini termasuk observasi kelas (dilakukan secara online), wawancara guru, kuisioner, dan tes menulis. 
Instrumen yang pertama adalah observasi kelas. Observasi kelas bertujuan untuk melihat implementasi dari strategi guru dalam membangun atau menjalin hubungan (rapport) dengan siswanya; apakah ada usaha untuk membangun hubungan atau tidak. Observasi kelas ini dilakukan dua kali. Adapun lembar observasi yang digunakan sebagai panduan dalam mengidentifikasi dan mengelompokkan strategi guru dalam membangun hubungan (rapport) dengan siswanya. Lembar observasi (checklist) ini dibuat dan disusun berdasarkan indikator hubungan guru-siswa dari penelitianpenelitian sebelumnya.

Instrumen yang kedua adalah wawancara. Wawancara guru dilakukan untuk menggali lebih dalam isu terkait strategi guru dalam membangun hubungan guru-siswa dan alasan di balik aksi yang diimplementasikan. Selanjutnya, wawancara semi terstruktur (semi structured interview) dipilih karena jenis wawancara ini memungkinkan peneliti untuk menambah, menghapus, atau mengimprovisasi pertanyaan berdasarkan tanggapan dari responden yang diwawancarai.

Instrumen yang ketiga adalah kuisioner. Student Instructor Relationship Scale (SIRS) yang dikembangkan oleh Creasey et al. (2009) dibagikan kepada siswa untuk mengukur dua dimensi hubungan guru-siswa (keterhubungan guru dan kecemasan siswa ketika berinteraksi dengan guru). Dalam SIRS, siswa diminta untuk menilai strategi guru dalam membangun hubungan dengan siswanya melalui skala Likert 7 poin $(1=$ sangat tidak setuju $-7=$ sangat setuju $)$. Ada 36 pernyataan dalam kuisioner ini. Akan tetapi, penelitian ini hanya mengambil pernyataan yang berhubungan dengan keterhubungan guru (11 pernyataan) dan kecemasan siswa dalam berinteraski dengan guru (8 pernyataan) seperti yang terlihat pada Tabel 1.

Tabel 1. Dua Dimensi dari SIRS

\begin{tabular}{ll}
\hline \multicolumn{1}{c}{ Dimensi } & \multicolumn{1}{c}{ Nomor Pernyataan } \\
\hline Keterhubungan guru & Pernyataan nomor 1, 4, 7, 8, 9, 10, 12, 14, 15, 18, and 19. \\
\hline $\begin{array}{l}\text { Kecemasan siswa dalam berinteraksi dengan } \\
\text { guru }\end{array}$ & Pernyataan nomor 2, 3, 5, 6, 11, 13, 16, and 17. \\
\hline
\end{tabular}

Instrumen yang keempat adalah tes menulis. Ini dilakukan untuk mengukur performa atau kemampuan menulis siswa. Dalam penelitian ini siswa diminta untuk menulis teks pendek dengan topik yang telah ditentukan oleh guru. Setelah semua teks pendek terkumpul, tiga guru yang terlibat akan menilai teks-teks tersebut.

Untuk instrumen pertama - observasi kelas_-karena lembar observasi (checklist) terkait strategi guru dalam membangun hubungan dengan siswa sebelumnya telah diklasifikasikan ke dalam beberapa kategori, maka peneliti hanya akan mendeskripsikan data yang terkumpul. Jika ada strategi baru yang ditemukan selama proses penelitian, peneliti akan mengklasifikasikan strategi tersebut berdasarkan teori atau temuan dari penelitian-penelitian sebelumnya.

Untuk instrumen kedua-wawancara-data hasil wawancara dianalisis melalui empat tahap. Pada tahap pertama, peneliti mengurutkan data. Pada tahap kedua, data ditranskripsi. Beberapa bagian-yang tidak perlu atau tidak relevan-dihapus pada tahap ini, sedangkan yang penting dimasukkan pada hasil dan pembahasan. Pada tahap ketiga, peneliti menarik kesimpulan dari data. Pada tahap keempat, peneliti menyajikan data melalui diskusi naratif yang juga diperkuat dengan teori dan dibandingkan dengan penelitian sebelumnya.

Untuk instrumen ketiga-kuisioner-adapun cara dalam menganalisis data yang diperoleh. Creasey et al. (2009) menyatakan bahwa skor tinggi pada dimensi keterhubungan guru menunjukkan kedekatan yang kuat antara guru dengan siswanya; sedangkan skor rendah menunjukkan penghindaran untuk menjalin hubungan yang dekat dengan guru. Di sisi lain, untuk dimensi kecemasan siswa, skor tinggi menunjukkan tingkat kecemasan yang dirasakan siswa saat berinteraksi dengan guru tinggi; 
sementara skor rendah pada dimensi ini berarti siswa menganggap berinteraksi dengan guru mereka tidak menakutkan sehingga mereka tidak akan sungkan atau merasa takut untuk berinteraksi dengan guru mereka.

Untuk instrumen keempat - tes menulis — rubrik analitik (analytic rubric) yang dikembangkan oleh Brown (2004) digunakan untuk menilai tulisan-tulisan siswa di penelitian ini. Sebuah rubrik disebut analitik apabila metode pemberian skor dibagi menjadi beberapa kategori sebelum akhirnya seluruh skor dijumlahkan. Dalam hal ini, rubrik yang digunakan terbagi menjadi lima kategori, yakni: organisasi (organization), isi (content), tata bahasa (grammar), kosa kata (vocabulary), dan mekanik (mechanics). Dalam setiap kategori ini, ada sub-kategori lagi berupa: sangat buruk, buruk, cukup, bagus, dan sangat bagus; dan masing-masing sub-kategori ini memiliki skala nilai 1-20 dengan 1 sebagai nilai terendah dan 20 sebagai nilai tertinggi. Meskipun menggunakan rubrik analitik memakan waktu lebih lama dibandingkan dengan memberikan skor secara keseluruhan, metode penilaian ini dipilih mengingat keunggulannya dalam mengingatkan guru dengan beberapa aspek penulisanorganisasi, isi, tata bahasa, kosa kata dan mekanik - yang mungkin diabaikan atau dilupakan.

Selanjutnya, untuk instrumen ketiga dan keempat-kuisioner dan tes menulis-data yang diperoleh akan digunakan untuk menghitung korelasi antara dua dimensi hubungan guru-siswa dengan performa menulis siswa. Selain untuk keperluan penghitungan korelasi, nilai hasil kuisioner siswa juga akan digunakan untuk melihat ada di titik mana-skala 1 sampai 7-rata-rata nilai hubungan gurusiswa dalam penelitian ini. Kemudian, untuk menginterpretasi dua nilai yang diperoleh-skor dimensi keterhubungan guru dan kecemasan siswa saat berinterkasi dengan guru dengan acuan di Tabel 2.

Tabel 2. Interpretasi Nilai Dimensi Rapport

\begin{tabular}{cc}
\hline Score & Interpretasi \\
\hline $1.00-2.20$ & Sangat rendah \\
\hline $2.21-3.40$ & Rendah \\
\hline $3.41-4.60$ & Cukup tinggi \\
\hline $4.61-5.80$ & Tinggi \\
\hline $5.81-7.00$ & Sangat tinggi \\
\hline
\end{tabular}

Setelah data kuisioner dan tes menulis terkumpul, uji normalitas terlebih dahulu dilakukan sebelum dapat menghitung nilai korelasi antara dua dimensi hubungan guru-siswa dan perfoma menulis siswa. Dalam penelitian ini, hasil dari uji normalitas menunjukan bahwa data yang tersebar terdistribusi secara normal. Kemudian, untuk mengetahui nilai korelasinya, SPSS digunakan untuk menghitung koefisien korelasi (r) antar variabel. Setelah nilai $\mathrm{r}$ ini diperoleh, langkah selanjutnya yang harus dilakukan adalah menginterpretasikan nilai tersebut - apakahada hubungan yang signifikan antara dua dimensi hubungan guru-siswa dan perfoma menulis siswa atau tidak. Korelasi antara dua variabel memiliki hubungan positif yang kuat ketika nilai $\mathrm{r}$ mendekati $+1,00$ dan dalam hubungan negatif yang kuat ketika nilai $\mathrm{r}$ mendekati -1,00. Dalam dua kasus ini, $\mathrm{H}_{\mathrm{o}}$ ditolak dan $\mathrm{H}_{\mathrm{a}}$ diterima. Namun jika koefisien korelasi mendekati 0 (nol), berarti hubungan antar variabel itu lemah yang mana hal ini menyebabkan $\mathrm{H}_{\mathrm{o}}$ diterima dan $\mathrm{H}_{\mathrm{a}}$ ditolak.

Akan tetapi, perhitungannya masih belum selesai; memastikan nilai $\mathrm{r}$ signifikan juga penting. Untuk itu, pengujian signifikansi nilai $r$ harus dilakukan. Untuk melakukan ini, rumus t digunakan untuk menguji hipotesis nol $\left(\mathrm{H}_{\mathrm{o}}\right)$ - apakah nilai $\mathrm{r}$ sama dengan nol atau tidak. Setelah dihitung, hasilnya (nilai p) harus kurang dari 0,05 untuk dianggap signifikan. Jika melebihi 0,05 berarti tidak ada hubungan yang signifikan antar variabel—baik positif maupun negatif. 


\section{HASIL DAN PEMBAHASAN \\ Hasil}

Hasil dari penelitian ini dipaparkan berdasarkan pertanyaan penelitiannya, yakni untuk menjawab: 1) strategi yang dilakukan guru untuk membangun rapport dengan siswanya selama pembelajaran online; dan 2) korelasi antara dua dimensi rapport dengan performe menulis siswa selama pembelajaran online.

Untuk menjawab pertanyaan pertama, observasi kelas (dilakukan secara online) dan wawancara dengan guru dilakukan. Observasi kelas dilakukan dua kali; sebelum dan sesudah wawancara. Data dari observasi digunakan untuk mengkonfirmasi data dari wawancara; apakah data tersebut benar adanya sesuai dengan yang terjadi di kelas online atau tidak. Data yang sudah dianalisis dan dikonfirmasi inilah yang kemudian dipaparkan. Kembali lagi ke pertanyaan pertama, hasil penelitian menunjukkan bahwa strategi yang dilakukan guru untuk membangun hubungan dengan siswanya adalah dengan mengenali siswa dan memberi dukungan atau membantu siswa baik di dalam atau di luar kelas online. Untuk lebih jelasnya, data yang diperoleh dapat di lihat di Tabel 3.

Tabel 3. Strategi Guru dalam Membangun Rapport

\begin{tabular}{|c|c|}
\hline Strategi Guru & Contoh Indikator Rapport \\
\hline \multirow[b]{2}{*}{ Mengenali siswa } & Mengenali wajah dan nama siswa \\
\hline & $\begin{array}{l}\text { Mengenali karakteristik, kebutuhan, dan kemampuan } \\
\text { siswa }\end{array}$ \\
\hline \multirow{5}{*}{ Mendukung/membantu siswa } & $\begin{array}{l}\text { Menawarkan bantuan kepada siswa di dalam dan di luar } \\
\text { kelas online }\end{array}$ \\
\hline & Bersedia membantu siswa di luar kelas online \\
\hline & Memberikan pujian \\
\hline & Memberikan feedback \\
\hline & Memperhatikan/mendengarkan apa yang dikatakan siswa \\
\hline \multirow{3}{*}{ Berinteraksi dengan siswa } & Tersedia, mudah dihubungi, dan responsif \\
\hline & Melakukan interaksi tatap muka (secara online) \\
\hline & Nada bicara yang ramah \\
\hline
\end{tabular}

Pada Tabel 3 di atas, dapat dilihat ada tiga strategi yang dilakukan guru untuk membangun rapport dengan siswanya selama pembelajaran online termasuk mengenali siswa, mendukung atau membantu siswa, dan berinteraksi dengan siswa. Adapun indikator rapport atau contoh dari aksi yang dilakukan guru di setiap kategorinya. Untuk indikator rapport yang berkaitan dengan mengenali siswa termasuk mengenali nama siswa beserta wajahnya dan mengenali karakteristik, kebutuhan, dan kemampuan siswa secara keseluruhan. Sedangkan indikator rapport yang berhubungan dengan mendukung atau membantu siswa khususnya dalam meningkatkan performa menulis siswa adalah 1) menawarkan bantuan kepada siswa di dalam dan di luar kelas online (misalnya melalui chat atau telepon); 2) bersedia membantu siswa di luar kelas online; 3) memberikan pujian; 4) memberikan tanggapan (feedback) langsung dan tidak langsung; dan 5) memperhatikan apa yang dikatakan siswa. Adapun beberapa indikator rapport yang berkaitan dengan interaksi antara guru dan siswa termasuk: 1) ketersediaan (tersedia saat siswa membutuhkan bantuan), aksesibilitas (mudah dihubungi oleh siswa), dan responsif (cepat merespon); 2) melakukan interaksi langsung (tatap muka secara online); 3) dan menggunakan nada bicara yang ramah. 
Untuk menjawab pertanyaan kedua, kuisioner dan tes menulis diadakan. Setelah data diperoleh, korelasi antara dua dimensi rapport-keterhubungan guru dan kecemasan siswa saat berinteraksi dengan guru-dengan perfoma siswa pun dihitung. Dalam penelitian ini, korelasi antara dimensi keterbubungan guru dengan perfoma menulis siswa memiliki nilai yang positif dan signifikan (Gambar 1); sedangkan korelasi antara dimensi kecemasan siswa dengan performa menulis siswa menunjukkan hubungan negatif dan signifikan (Gambar 2).

\begin{tabular}{llr|r} 
& & $\begin{array}{c}\text { Connectedne } \\
\text { ss }\end{array}$ & \multicolumn{1}{c}{ Writing } \\
\hline Connectedness & Pearson Correlation & 1 & $.701^{\star \star}$ \\
\cline { 2 - 4 } & Sig. (2-tailed) & & .000 \\
\cline { 2 - 4 } & $\mathrm{N}$ & 70 & 70 \\
\hline \multirow{3}{*}{ Writing } & Pearson Correlation & $.701^{\star \star}$ & 1 \\
\cline { 2 - 4 } & Sig. (2-tailed) & .000 & \\
\cline { 2 - 4 } & $\mathrm{N}$ & 70 & 70 \\
\hline
\end{tabular}

**. Correlation is significant at the 0.01 level (2-tailed).

Gambar 1. Korelasi antara Keterhubungan Guru dengan Performa Menulis Siswa

Seperti yang dapat dilihat pada Gambar 1, nilai 0,701 menunjukkan nilai korelasi yang positif dan signifikan antara dimensi keterhubungan guru dengan performa menulis siswa.

\begin{tabular}{ll|r|r} 
& & \multicolumn{1}{c}{ Anxiety } & \multicolumn{1}{c}{ Writing } \\
\hline \multirow{2}{*}{ Anxiety } & Pearson Correlation & 1 & $-.305^{\star}$ \\
\cline { 2 - 4 } & Sig. (2-tailed) & & .010 \\
\cline { 2 - 4 } & $\mathrm{N}$ & 70 & 70 \\
\hline \multirow{2}{*}{ Writing } & Pearson Correlation & $-.305^{\star}$ & 1 \\
\cline { 2 - 4 } & Sig. (2-tailed) & .010 & \\
\cline { 2 - 4 } & $\mathrm{N}$ & 70 & 70 \\
\hline
\end{tabular}

${ }^{*}$. Correlation is significant at the 0.05 level ( 2 tailed).

Gambar 2. Korelasi antara Kecemasan Siswa dengan Performa Menulis Siswa

Nilai -0,305 pada Gambar 2 menunjukkan nilai korelasi yang negatif dan signifikan antara performa menulis siswa dengan dimensi kecemasan siswa saat berinteraksi dengan guru.

\section{Pembahasan}

Dalam wawancara, guru yang terlibat mengakui bahwa dia berusaha untuk menghafal nama dan wajah siswa meskipun hal tersebut cukup sulit untuk dilakukan selama pembelajaran online. Akan tetapi, dia menyatakan bahwa mengenali nama dan wajah siswa adalah langkah pertama untuk membangun rapport dengan siswa. Pandangan ini sejalan dengan Harmer (2007) yang menyatakan bahwa cara pertama dan paling sederhana untuk membangun hubungan dengan siswa adalah dengan mengetahui dan mengingat nama mereka. 
Guru yang terlibat lebih lanjut menjelaskan bahwa butuh beberapa waktu baginya untuk menghafal dan mengenali nama dan wajah siswa selama pembelajaran online. Untuk mengatasi masalah ini, pada semester pertama, dia meminta siswanya untuk memasang name tag selama kelas berlangsung. Kemudian, setiap kali ada kerja kelompok, dia akan menghabiskan sekitar lima hingga sepuluh menit untuk melakukan panggilan video dengan setiap kelompok sehingga lebih mudah baginya untuk mengenali nama siswa beserta wajah mereka.

Strategi guru yang disebutkan di atas - meminta siswa untuk memasang name tag selama kelas berlangsung dan melakukan video call dengan tiap kelompok saat ada tugas kelompok - mencerminkan salah satu indikator hubungan guru-siswa khususnya yang berhubungan dengan mengumpulkan informasi siswa (keeping track of students' information). Selain itu, menjelang akhir pernyataan, guru juga mencerminkan indikator hubungan guru-siswa lainnya yang berkaitan dengan memahami siswa sebagai individual. Sejalan dengan ini, Narváez sebagaimana dikutip dalam Sánchez et al. (2013), menemukan bahwa ada dua cara yang akan dilakukan siswa untuk mengkonseptualisasikan guru mereka, yakni sebagai individual dan profesional. Adapun yang pertama, siswa akan mengharapkan guru mereka untuk tertarik pada mereka secara pribadi atau individual. Sedangkan untuk yang kedua, siswa akan mempersepsikan gurunya berdasarkan komitmen dan dedikasi yang diberikan oleh guru dalam praktik mengajar. Berdasarkan hal ini, siswa menginginkan guru yang benar-benar peduli terhadap dirinya — secara individual — dan tidak menganggap profesinya hanya sebagai pekerjaan.

Lebih lanjut lagi, berdasarkan data yang diperoleh dari observasi kelas yang dilakukan dua kali, tampaknya strategi guru untuk mengenali siswa efektif dan berhasil. Hal ini dapat dilihat dari kebiasaan guru yang terus memanggil siswa dengan nama mereka ketika menanyakan sesuatu atau hanya memastikan bahwa siswa tersebut memperhatikan pelajaran yang berlangsung.

Tak hanya mengenali nama dan wajah siswa, untuk membangun hubungan guru-siswa yang baik, mengenali karakteristik, kebutuhan, dan kemampuan siswa secara keseluruhan juga penting. Hal ini, sayangnya, jauh lebih menantang untuk dilakukan selama pembelajaran online. Untuk mengatasi masalah ini, pada semester pertama, guru meminta siswa untuk membuat teks deskriptif tentang diri mereka sendiri dan mencoba untuk mengenal mereka melalui teks ini. Dengan melakukan ini, guru setidaknya memiliki informasi dasar yang berkaitan dengan latar belakang siswa, minat, kebutuhan, dan kemampuan menulis awal siswa.

Strategi guru yang diuraikan di atas juga sesuai dengan salah satu indikator hubungan guru-siswa dalam mengenali siswa yang disebutkan oleh Murphy dan Rodríguez-Manzanares (2012) khususnya yang berhubungan dengan mengumpulkan informasi siswa terkait dengan preferensi mereka (keeping track of students' information). Kemudian, ditambah dari data observasi kelas, guru juga mencerminkan indikator lain yang berkaitan dengan terlibat dalam diskusi personal selama kelas berlangsung (engaging in personal discussions). Indikator ini tercermin melalui tindakan guru seperti memulai obrolan ringan (small talk) sebelum kelas dimulai dan terkadang mengajukan beberapa pertanyaan kepada siswa yang bersifat pribadi namun tetap relevan dengan topik pelajaran.

Dalam wawancara, guru yang terlibat juga menekankan pentingnya membangun hubungan yang positif dengan siswa serta mengetahui karakteristik, kebutuhan, minat, dan kemampuan awal siswa karena aspek-aspek tersebut dapat digunakan sebagai informasi dasar untuk membuat materi pembelajaran dan mengembangkan metode mengajar yang sesuai dengan kebutuhan dan perbedaan siswa.

Strategi-strategi yang berhubungan dengan mendukung atau membantu siswa khususnya dalam meningkatkan performa menulis siswa termasuk: menawarkan bantuan dan bersedia membantu siswa di dalam dan di luar kelas online, di luar kelas online, memberikan pujian, memperhatikan apa yang dikatakan siswa dengan seksama, dan memberikan tanggapan (feedback). 
Untuk strategi pertama - menawarkan bantuan kepada siswa di dalam dan di luar kelas onlineditemukan bahwa guru yang terlibat memandang memiliki hubungan yang positif dengan siswa itu penting dari data wawancara. Untuk alasan ini, dia berusaha membangun dan mempertahankan hubungannya dengan siswa dengan terus berinteraksi selama dan di luar kelas online. WhatsAppgroup chat atau personal chat-dan telepon dapat digunakan sebagai perantara untuk menghubungi guru jika siswa membutuhkan bantuan. Guru yang bersangkutan juga memberi tahu siswanya kalau mereka dapat menghubunginya kapan saja.

Temuan yang diuraikan di atas juga didukung oleh data dari observasi kelas-biasanya, guru menawarkan bantuan kepada siswa selama kelas dengan menyatakan "you can tell me if there's something you haven't understood yet" (kalian bisa memberitahu saya jika ada hal yang masih belum dimengerti); "ask me anything, I'll try to help" (tanya apapun pada saya, saya akan mencoba untuk menolong); dan banyak lagi. Sebelum menutup kelas, guru yang terlibat juga mengingatkan siswanya untuk tidak sungkan menghubunginya jika mereka suatu waktu mereka membutuhkan bantuan atau sekedar menanyakan beberapa pertanyaan. Strategi guru ini mencerminkan dua indikator hubungan guru-siswa termasuk menunjukkan kepedulian (showing care) dan memberikan bimbingan (providing guidance).

Beranjak ke strategi selanjutnya, guru juga tidak lupa untuk memberikan apresiasi kepada siswa melalui pujian. Pujian ini dilakukan dengan dua cara, yaitu verbal dan non-verbal. Berdasarkan data dari observasi kelas, guru sering mengatakan "brilliant"; "you did great job"; "good job"; dan "good explanation”, terutama kepada siswa yang bersedia untuk berbagi ide dan pendapat mereka. Selama pembelajaran berlangsung, guru juga mendorong siswanya untuk berbicara menggunakan bahasa Inggris.

Lebih lanjut lagi, adapun alasan dibalik mengapa guru dalam penelitian ini memberikan pujian kepada siswanya, yakni untuk menunjukkan apresiasi terhadap tindakan siswa, meningkatkan kepercayaan diri siswa, memotivasi siswa untuk lebih seringberbicara dalam bahasa Inggris, dan membuat siswa merasa dihargai. Strategi guru ini juga mencerminkan indikator hubungan guru-siswa khususnya dalam membantu dan mendorong siswa untuk berhasil (helping and encouraging students to succeed). Selain pujian verbal, guru juga terkadang menggunakan beberapa gerakan non-verbal untuk menghargai tindakan siswa. Melalui observasi kelas, guru biasanya mengacungkan jempol sambil tersenyum.

Selain memberikan pujian kepada siswa, guru dalam penelitian ini juga memberikan apresiasi kepada siswa dengan memperhatikan apa yang dikatakan oleh siswa dengan seksama. Hal ini termasuk ke salah satu strategi yang dilakukan guru dalam mendukung dan membantu siswa. Melalui observasi kelas, setiap kali siswa berbicara, guru mendengarkan dengan penuh perhatian tanpa menyela—untuk kebanyakan situasi, dia hanya berbicara ketika siswa tampaknya tidak tahu harus berkata apa, jadi dia menyela hanya untuk membantu mereka. Guru juga mengingatkan siswa lain untuk memperhatikan siapa pun yang berbicara.

Dari data wawancara, guru yang terlibat memandang mendengarkan siswa dengan seksama perlu dilakukan terutama untuk mendorong siswa agar mereka dapat dengan nyaman berbagi pendapat, ide, dan perasaan mereka tanpa merasa takut guru akan menyela atau tidak menyukai apa yang mereka coba sampaikan. Pandangan guru dalam hal ini sejalan dengan Harmer (2007) yang menyatakan bahwa siswa mungkin merasa putus asa dan kecewa jika guru mereka tidak mendengarkan pendapat mereka dan memilih untuk menyela. Lebih lanjut lagi, Harmer menekankan sikap seperti itu-menyela siswa-dapat menyebabkan siswa menjadi tidak tertarik untuk mengutarakan pendapat mereka di kemudian hari. Selain itu, menghargai siswa merupakan elemen penting untuk membangun hubungan guru-siswa yang positif (Harmer, 2007). Selain memperhatikan atau mendengarkan siswa dengan 
seksama, dari observasi kelas yang dilakukan, guru juga memberikan waktu yang cukup kepada siswa untuk menyampaikan ide atau pendapatnya.

Menurut Murphy dan Rodríguez-Manzanares (2012), ada beberapa aspek lain yang perlu dipertimbangkan seorang guru dalam membangun hubungan dengan siswa selama pembelajaran online, termasuk: 1) ketersediaan, aksesibilitas, dan respon (availability, accessibility, and responsiveness); 2) interaksi di luar chat (non text-based interactions); dan 3) nada bicara (tone of interactions). Strategi guru mengenai aspek pertama-ketersediaan, aksesibilitas, dan respon-dapat dilihat pada kutipan di bawah ini:

\section{Kutipan 1}

Saya berusaha untuk membangun hubungan yang baik dengan berinteraksi terus dengan siswa baik di kelas atau misal mereka ingin personally call or text untuk nanya seputar tugas dan pelajaran misal, saya tidak masalah. Saya selalu bilang mereka boleh kontak saya via whatsapp atau telepon kapan saja kalau ada perlu.

Mengacu pada Kutipan 1 di atas, terlihat bahwa guru tidak membatasi siswa untuk berinteraksi secara ketat dengannya selama kelas online saja. Dengan kata lain, para siswa dapat menghubunginya kapan pun mereka membutuhkan bantuan melalui WhatsApp atau telepon.

Sebagaimana telah disebutkan dalam sesi pendahuluan, beberapa penelitian (lihat Alawamleh et al., 2020; Putri et al., 2020; Siswati et al., 2020) menekankan interaksi dan komunikasi antara guru dan siswa sebagai salah satu aspek yang paling terpengaruh selama pembelajaran online. Dalam penelitian mereka, sebagian besar siswa melihat pembelajaran online membatasi interaksi mereka dengan guru dan teman sekelas lainnya yang kemudian menyebabkan mereka merasa kurang terhubung (Alawamleh et al., 2020) dan cemas karena kurangnya hubungan emosional (Siswati et al., 2020). Namun, dari Kutipan 1 terlihat bahwa ketersediaan, aksesibilitas, dan repson guru semuanya hadir selama pembelajaran online. Hal ini diharapkan dapat membantu siswa untuk tidak merasa terhubung dengan guru bahasa Inggris mereka meskipun terpisah jarak.

Beralih ke aspek kedua - tentang interaksi di luar chat - hal ini berkaitan dengan strategi guru untuk berinteraksi dengan siswanya secara real-time dan tatap muka melalui pertemuan online. Pertemuan online perlu dilakukan mengingat hal ini dapat membantu guru dalam membangun dan menjalin hubungan dengan siswanya. Kemudian melalui wawancara, diketahui bahwa guru menggunakan Zoom sebagai media online untuk bertemu dengan siswa-siswanya sekaligus menyampaikan pelajaran.

Beranjak ke aspek ketiga, Murphy dan Rodríguez-Manzanares (2012) menyatakan hubungan guru-siswa juga ada relasinya dengan penggunaan nada bicara yang positif saat interaksi. Mereka lebih lanjut menjelaskan indikator rapport untuk aspek ini termasuk bersikap ramah, humoris, dan saling menghormati. Melalui observasi kelas, guru memiliki dan menerapkan indikator rapport ini ke dalam praktik pengajarannya. Misalnya, indikator ramah dapat dilihat dari bagaimana guru memulai obrolan ringan (small talk) sebelum kelas dimulai dan bertanya kepada siswa bagaimana kabar mereka sambil memeriksa absensi dengan menggunakan nada yang menenangkan dan ramah. Selanjutnya, indikator humoris terlihat ketika guru sesekali melontarkan lelucon tanpa menyinggung perasaan siapa pun. Terakhir, indikator sikap hormat terlihat ketika guru memberikan tannggapan (feedback) secara lisan dan ketika dia mendengarkan apa yang dikatakan siswa tanpa menyela.

Seperti yang telah disebutkan sebelumnya bahwa ada dua dimensi rapport dalam penelitian ini-keterhubungan guru dan kecemasan siswa saat berinteraksi dengan guru-dan perhitungan korelasi akan dilakukan secara terpisah. 
Untuk dimensi keterhubungan guru, berdasarkan uji statistik dengan menggunakan Pearson Correlation, diketahui bahwa nilai $\mathrm{r}$ antara keterhubungan guru dan performa menulis siswa adalah 0,701. Nilai tersebut lebih besar dari 0,50 yang mana berarti terdapat hubungan positif yang kuat antar variabel. Penelitian sebelumnya yang dilakukan oleh Lammers et al. (2017) juga memiliki hasil yang serupa. Meskipun mereka berfokus pada korelasi antara skor hubungan guru-siswa dan nilai akhir siswa, penelitian tersebut mengungkapkan bahwa siswa dengan skor rapport yang menurun sepanjang semester menunjukkan nilai akhir yang lebih rendah secara signifikan dibandingkan dengan mereka yang memiliki skor rapport yang stabil sepanjang semester.

Lebih jauh lagi, nilai $p$ untuk dimensi ini adalah 0,000. Nilai ini lebih kecil dari 0,05 yang berarti hubungan antar variabel signifikan. Kesimpulan yang dapat diambil dari hasil perhitungan ini adalah ada korelasi positif dan signifikan antara keterhubungan guru dan performa menulis siswa.

Untuk dimensi kecemasan siswa saat berinteraksi dengan guru, berdasarkan uji statistik yang dilakukan dengan menggunakan SPSS, diketahui bahwa nilai $r$ antar variabel adalah $-0,305$. Selanjutnya, dengan nilai signifikansi yang sebesar 0,010 - lebih kecil dari 0,05-menunjukkan bahwa hubungan antar variabel adalah signifikan. Kesimpulannya, ada hubungan negatif yang signifikan antara kecemasan siswa saat berinteraksi dengan guru dan performa menulis siswa. Kemudian, selain dilihat dari hasil korelasi antara dua dimensi hubungan guru-siswa dengan performa menulis siswa, nilai rata-rata dari dua dimensi ini pun dihitung untuk mendukung data korelasi. Nilai rata-rata ini diinterpretasikan dengan mengikuti Tabel 2. Pada dimensi keterhubungan guru, seperti yang telah diilustrasikan pada Gambar 3, didapatkan rata-rata skor 4,99 yang menandakan tingkat keterhubungan yang tinggi antara guru dan siswa.

Pada Gambar 4, dapat dilihat bahwa untuk dimensi kecemasan siswa saat berinteraksi dengan guru didapatkan skor rata-rata 3,27 yang berada di bawah kategori rendah. Dengan kata lain, hasil ini menunjukkan bahwa tingkat kecemasan siswa adalah rendah ketika mereka berinteraksi dengan guru bahasa Inggris mereka.

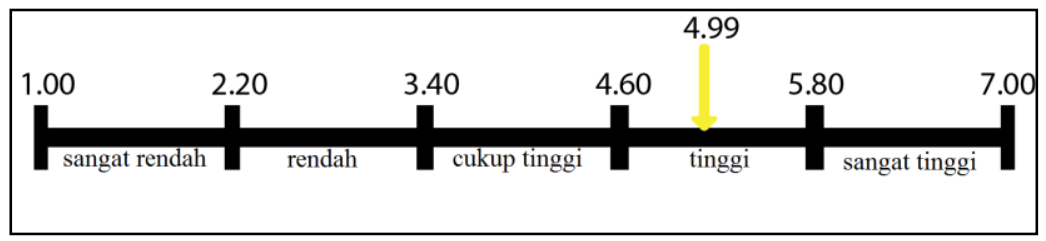

Gambar 3. Nilai Rata-Rata Keterhubungan Guru

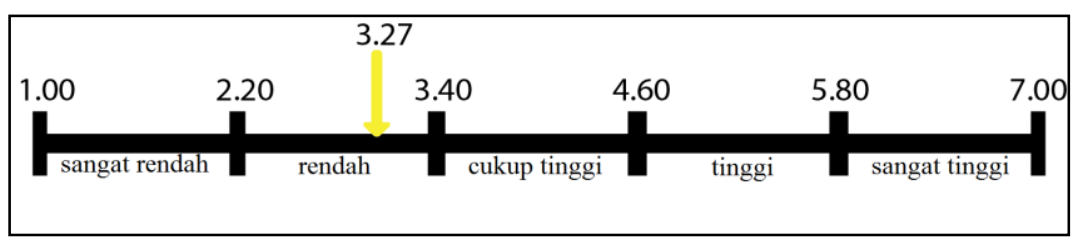

Gambar 4. Nilai Rata-Rata Kecemasan Siswa

\section{KESIMPULAN}

Tujuan dari penelitian ini adalah untuk menyelidiki strategi guru dalam membangun rapport dengan siswanya dan bagaimana hal tersebut berkolerasi dengan performa menulis siswa. Berdasarkan temuan pada penelitian ini, strategi paling mendasar yang dilakukan oleh guru untuk membangun hubungan interpersonal yang positif dengan siswanya adalah dengan mengenali siswa. Akan tetapi, perlu diingat bahwa mengenali siswa tidak berhenti saat guru mengetahui dan dapat mengidentifikasi 
nama dan wajah siswanya; guru juga harus mengenali karakter dan kemampuan siswa sehingga materi pelajaran yang dikembangkan dapat mengakomodasi kemampuan majoritas siswa. Strategi selanjutnya adalah dengan memberi dukungan dan membantu siswa. Hal ini dapat disalurkan dengan menawarkan dan bersedia menolong siswa baik di dalam atau di luar kelas online. Dengan kata lain, guru tidak membatasi siswanya dalam meminta bantuan atau bimbingan. Memberikan pujian dan feedback juga merupakan bentuk lain dari dukungan dan bantuan. Strategi yang terakhir berkaitan dengan interaksi yang dilakukan oleh guru dengan siswanya agar rapport yang sudah terjalin senantiasa tetap terjaga. Hal ini dapat dilakukan dengan menjadi: guru yang ada (available), mudah dihubungi, dan cepat merespon saat siswa membutuhkan bantuan terkait pelajaran; mengusahakan untuk melakukan kelas tatap muka secara online dan menggunakan nada bicara yang ramah.

Dengan strategi yang disebutkan di atas, hasil perhitungan korelasi yang diperoleh pun menunjukkan hasil yang memuaskan. Dari dua dimensi rapport, dimensi keterhubungan guru mendapat hasil korelasi yang positif dan signifikan dengan performa menulis siswa; sedangkan dimensi kecemasan siswa memiliki hasil korelasi negatif dan signifikan dengan kecemasan siswa saat mereka berinteraksi dengan guru bahasa Inggris mereka.

Temuan dari penelitian ini menunjukkan bahwa memiliki hubungan guru-siswa yang positif merupakan kunci dari terciptanya suasana kelas yang ramah dan menenangkan. Hal ini dapat dilihat dari tingkat kedekatan (keterhubungan) antara guru dan siswa yang tinggi dan juga rasa khawatir yang rendah saat siswa berinteraksi dengan gurunya selama pembelajaran online. Oleh karenanya, sangat penting bagi guru untuk mengetahui strategi apa yang harus dilakukan untuk membangun hubungan yang positif dengan siswanya, khususnya saat pembelajaran online dimana interaksi dan komunikasiyang menjadi dasar dari rapport—menjadi aspek yang paling terpengaruhi.

\section{DAFTAR PUSTAKA}

Alawamleh, M., Al-Twait, L. M., \& Al-Saht, G. R. (2020). The effect of online learning on communication between instructors and students during Covid-a19 pandemic. Asian Education and Development Studies, 14, 1-22. http://doi.org/10.1108/AEDS-06-2020-0131

Brown, H. D. (2004). Language assessment, principle and classroom practice. Longman.

Chávez, A. J. G., Maldonado, E. Y. C., Zamarrón, R. C., \& Villar, M. M. B. (2017). The effective use of positive rapport in EFL students. Research Gate. http://www.researchgate.net/publication/330524347

Creasey, G., Jarvis, P., \& Knapcik, E. (2009). A measure to assess student instructor relationships. International Journal for the Scholarship of Teaching and Learning, 3, 1-7.

Creswell, J. W., Plano, C. V L., Gutmann, M. L., \& Hanson, W. E. (2006). Advances in mixed methods research designs. In A. Tashakkori \& C. Teddlie (Eds.), Handbook of mixed methods in social and behavioral research (pp. 58-88). SAGE Publications.

Erawati, M. (2016). Pembentukan rapport di kelas: Analisis psikologi. PSIKOHUMANIORA: Jurnal Penelitian Psikologi, 1(1), 75-94.

Fatoni, Arifiati, N., Nurkhayati, E., Nurdiawati, E., Fidziah, Pamungkas, G., Adha, S., Irawan, Purwanto, A., Julyanto, O., \& Azizi, E. (2020). University students online learning system during Covid-19 pandemic: Advantages, constraints and solutions. Sys Rev Pharm, 11(7), 570-576.

Harmer, J. (2007). The practice of English language teaching. Longman.

Lammers, W. J., Gillaspy, J. A., \& Hancock, F. (2017). Predicting academic success with early, middle, and late semester assessment of student-instructor rapport. Teaching of Psychology, 44(2), 145-149. http://doi.org/10.1177/0098628317692618 
Marpaung, J. N., \& Cendana, W. (2020). Keterampilan menjelaskan guru untuk membangun minat keterlibatan siswa dalam pembelajaran online. Jurnal Inovasi Penelitian, 1(7), 1245-1250.

Merell, K. W. (2008). Helping students overcome depression and anxiety: A practical guide (2nd ed.). The Guilford Press.

Murphy, E., \& Rodríguez-Manzanares, M. A. (2012). Rapport in distance education. The international Review of Research in Open and Distance Learning, 13(1), 167-190).

Nova, M., \& Sukyadi, D. (2017). An innovation of teacher's self-assessment of rapport building in EFL classroom. The 1st Education and Language International Conference Proceedings Center for International Language Development of Unissula. Sultan Agung Press.

Putri, R. S., Purwanto, A., Pramono, R., Asbari, M., Wijayanti, L. M., \& Choi, C. H. (2020). Impact ofthe Covid-19 pandemic on online home learning: An explorative study of primary schools in Indonesia. International Journal of Advanced Science and Technology, 29(05), 4809-4818.

Sánchez, C., González, B. \& Martínez, C. (2013). The impact of teacher-student relationships on EFL learning. A Colombian Journal for Teachers of English, 20, 16-129.

Satriani, M. (2020). Teacher-student rapport and students' speaking performance in ELT [Tesis, Universitas Pendidikan Indonesia]. https://shorturl.at/lwDQ7

Siswati, S., Astiena, A. K., \& Savitri, Y. (2020). Evaluation of online-based student learning: Models during new normal pandemic Covid-19 in Indonesia. Journal of Nonformal Education, 6(2), 148155. http://doi.org/10.15294/jne.v6i2.25599

Smith, K., \& Robertson, R. (2020). What they thought they knew: Student-Instructor relationships and expectancy in community college classrooms. Community College Journal of Research and Practice. http://doi.org/10.1080/10668926.2020.1829178 